$\begin{array}{ll}\text { Received } & : \text { 2 June } 2019 \\ \text { Revised } & : \text { 20 June } 2019 \\ \text { Accepted } & : \text { 26 June } 2019 \\ \text { Published } & : \text { 30 June } 2019\end{array}$

\title{
The Diction and Language Style in Sutardji Calzoum Bachri's Contemporary Poetry (A Study on Stilistics)
}

\author{
Satinem $^{1, a)}$, Juwati ${ }^{1, b)}$ \\ STKIP PGRI Lubuklinggau, Lubuklinggau, Indonesia \\ E-mail: ${ }^{a)}$ y.sartinem@yahoo.co.id, b) watiaja56@ymail.com
}

\begin{abstract}
The purpose of this study was to examine contemporary poetry by Sutardji Calzoum Bachri using the stylistic approach. The research method used is based on content analysis. The object of this research is contemporary poems entitled Husspuss, O, Mantera, Sepisaupi, and Tapi. The method used in this study is a qualitative method. The results and discussion in this study in the poems of Husspuss, O, Mantera, Sepisaupi, and Tapi shows that there are many elements of rhyme, rhythm, sound play, and sound repetition that are incorporated in the characteristics of sound and meaning of poetry while the style of language contained in these contemporary poems received less attention from the poet. The poet uses only a few styles of language such as hyperbole and repetition.
\end{abstract}

Keywords: diction, style, contemporary poetry, stylistic

\begin{abstract}
Abstrak
Penelitian ini bertujuan untuk mengkaji puisi kontemporer karya Sutardji Calzoum Bachri dengan menggunakan pendekatan stilistik. Metode penelitian yang digunakan berbasis content analysis. Objek penelitian ini adalah puisi-puisi kontemporer yang berjudul Husspuss, O, Mantera, Sepisaupi, dan Tapi yang mewakili sebagian dari puisi kontemporer karya Sutardji Calzoum Bachri. Metode yang digunakan dalam penelitian ini adalah metode kualitatif. Hasil dan pembahasan dalam penelitian ini dalam puisi Husspuss, O, Mantera, Sepisaupi, dan Tapi banyak terdapat unsur rima, irama, permainan bunyi, dan perulangan bunyi yang tergabung dalam karakteristik bunyi dan makna puisi, sedangkan gaya bahasa yang terdapat dalam puisi-puisi kontemporer tersebut kurang mendapat perhatian dari sang penyair. Penyair hanya menggunakan beberapa gaya bahasa seperti gaya bahasa hiperbola dan repetisi.
\end{abstract}

Kata kunci: diksi, gaya bahasa, puisi kontemporer, stilistik 


\section{PENDAHULUAN}

Karya sastra merupakan wujud permainan kata-kata pengarang yang berisi maksud tertentu yang akan disampaikan kepada penikmat sastra. Karya sastra adalah wacana yang khas yang di dalam ekspresinya menggunakan bahasa dengan memanfaatkan segala kemungkinan yang tersedia. Dengan demikian, bahasa merupakan salah satu unsur terpenting dalam sebuah karya sastra. Oleh karena itu, sastra dan bahasa merupakan dua bidang yang tidak dapat dipisahkan.

Wujud karya sastra yang paling menonjol dari penggunaan bahasa sehingga menimbulkan estetika adalah puisi. Puisi memiliki ciri khas tersendiri dalam hal penggunaan bahasa. Bahasa dalam puisi merupakan bahan mentah yang diolah penyair menjadi sebuah karya sastra. Penempatan kata demi kata oleh penyair merupakan wujud dari proses kelahiran sebuah puisi. Pradopo (2002) mengatakan bahwa puisi merupakan karya estetis yang bermakna, yang mempunyai arti, bukan hanya sesuatu yang kosong tanpa makna. Memperkuat pendapat Pradopo, Lastari (2017), menyatakan bahwa sebagai sebuah karya sastra, puisi merupakan gambaran atas pikiran dan perasaan penyair saat bersentuhan dengan realitas kehidupan. Selain mempunyai pesan yang ingin disampaikan oleh pengarang, puisi juga disusun menggunakan bahasa yang khas maupun penempatan antar kata yang disusun sedemikian rupa dengan penyepadanan bunyi.

Demikian halnya dengan puisi kontemporer. Puisi kontemporer adalah karya sastra yang muncul sekitar tahun 70-an, bersifat eksperimental, dan memiliki sifat-sifat yang "menyimpang" dari konvensi-konvensi sastra yang berlaku biasa atau umum. Ciri khas sebuah karya sastra tidak saja dilihat berdasarkan genrenya, tetapi dapat pula dilihat melalui konvensi sastra maupun konvensi bahasa. Pada konteks kaitan bahasa dalam sastra, pengarang mengeksploitasi potensi-potensi bahasa untuk menyampaikan gagasannya dengan tujuan tertentu. Dengan sudut pandang demikian dapat dikatakan bahwa ada kekhususan atau keunikan masing-masing pengarang sebagai ciri khasnya yang mungkin merupakan kesengajaan atau invensi pengarang dalam proses kreatifnya. Dalam hal ini, sastra kontemporer muncul sebagai reaksi terhadap sastra konvensional yang sudah beku dan tidak kreatif.

Jenis puisi kontemporer mulai dipopulerkan sejak tahun 1970-an oleh Sutardji Calzoum Bachri. Sutardji mulai tidak mempercayai kekuatan kata tetapi dia mulai berpaling pada eksistensi bunyi dan kekuatannya. Adapun ciri-ciri puisi kontemporer bergaya mantra dengan sarana kepuitisan berupa pengulangan kata, frasa, atau kalimat. Gaya bahasa paralelisme yang dikombinasikan dengan gaya bahasa hiperbola dan enumerasi dipergunakan penyair untuk memperoleh efek pengucapan maksimal. Tipografi puisi dieksploitasi secara sugesti dan kata-kata nonsens dipergunakan serta diberi makna baru.

Hal inilah yang membuat puisi kontemporer menarik untuk dikaji lebih lanjut. Keindahan adalah ciptaan pengarang dengan seperangkat bahasa. Melalui eksplorasi bahasa yang khas, pengarang akan menampilkan aspek keindahan yang optimal. Untuk mengkaji aspek kebahasaan dalam karya sastra lazimnya dikategorikan sebagai kajian stilistika.

Stilistika adalah ilmu tentang gaya bahasa (style). Gaya merupakan perwujudan penggunaan bahasa oleh seorang penulis untuk mengemukakan gambaran, gagasan, pendapat, dan membuahkan efek tertentu bagi penanggapnya sebagaimana cara yang 
digunakannya (Ratna, 2009; Purwahida, 2017). Menurut Muljana (dalam Pradopo, 2010), gaya bahasa adalah susunan perkataan yang terjadi karena perasaan yang timbul atau hidup dalam hati penulis yang menimbulkan suatu perasaan tertentu dalam hati pembaca.

Kajian stilistika dimaknai sebagai kajian terhadap wujud performansi kebahasaan, khususnya yang terdapat di dalam teks-teks kesastraan (Supriyanto, 2011; Purwahida, 2018). Dalam kajian stilistika, cara pendekatan yang dapat digunakan ada dua macam, yaitu (1) menganalisis sistem linguistik karya sastra yang dilanjutkan dengan interpretasi ciri-cirinya dilihat dari tujuan estetis karya sastra sebagai makna total, (2) mengamati deviasi dan distorsi terhadap pemakaian bahasa yang normal (dengan metode kontras) dan berusaha menemukan tujuan estetis (Wellek dalam Munir, 2013; Suhita \& Purwahida, 2018). Endraswara (2011) juga mengatakan bahwa bahasa memiliki pesan keindahan sekaligus pembawa makna. Tanpa keindahan bahasa, karya sastra menjadi hambar. Keindahan suatu sastra dipengaruhi oleh kemampuan penulis mengolah kata.

Kajian stilistika pada hakikatnya adalah aktivitas mengekplorasi kreativitas penggunaan bahasa. Kajian stilistik membawa ke pemahaman tentang bagaimana bahasa dapat dikreasikan dan didayakan sedemikian rupa baik lewat penyimpangan, pengulangan, penekanan, bahkan penciptaan ungkapan baru. Menurut Simpson (dalam Nurgiyantoro, 2014), objek kajian stilistika meliputi seluruh aspek kebahasaan, mulai dari aspek bunyi, diksi, sampai grafologi dan bahkan bentuk visual dalam puisi. Namun, dalam praktiknya, pembaca diberi kebebasan memilih unsur-unsur tertentu yang diminati. Selanjutnya, Sudjiman (dalam Nurhayati, 2008) mengemukakan titik berat pengkajian stilistik adalah terletak pada penggunaan bahasa dan gaya bahasa suatu sastra, tetapi tujuan utamanya adalah meneliti efek estetika bahasa.

Dengan demikian, dapat dikatakan bahwa kajian stilistika merupakan jembatan antara bahasa dan sastra untuk saling memahami antara keduanya. Stilistika hadir untuk mengupas lebih dalam keindahan yang ada di dalam bahasa sehingga makna yang disampaikan oleh penulis dapat tersalurkan. Kajian stilistika berupaya menunjukkan bagaimana unsur-unsur suatu teks berkombinasi membentuk suatu pesan. Kajian stilistika juga memberikan kontribusi dengan berusaha mengurangi subjektivitas dan menampilkan interpretasi berdasarkan pemunculan unsur-unsur bunyi yang terdapat dalam sastra itu sendiri namun tidak melupakan kesan intuitif. Secara umum, lingkup telaah stilistika mencakup diksi atau pilihan kata (pilihan leksikal), struktur kalimat, majas, citraan, pola rima. Selain itu, aspek-aspek bahasa yang ditelaah dalam studi stilistika meliputi intonasi, bunyi, kata, dan kalimat sehingga lahirlah gaya intonasi, gaya bunyi, gaya kata, dan gaya kalimat.

Terkait hal tersebut, peneliti ini bertujuan untuk mengkaji puisi-puisi kontemporer karya Sutardji Calzoum Bachri dengan menggunakan pendekatan stilistik yang menitikberatkan pada aspek diksi dan gaya bahasa yang digunakan penyair. Adapun puisi-puisi yang dijadikan objek penelitian yaitu puisi Husspuss, O, Mantera, Sepisaupi,dan Tapi yang mewakili sebagian dari puisi-puisi kontemporer karya Sutardji Calzoum Bachri.

\section{METODE PENELITIAN}

Penelitian ini adalah penelitian berbasis analisis isi. Objek penelitian ini adalah puisi-puisi kontemporer karya Sutardji Calzoum Bahri yang dikaji dengan 
menggunakan pendekatan stilistik. Metode yang digunakan dalam penelitian ini adalah metode kualitatif. Penelitian kualitatif merupakan penelitian yang temuan-temuannya tidak diperoleh melalui prosedur statistik atau bentuk hitungan lain. Artinya, penelitian yang hanya menjelaskan secara deskriptif makna yang terkandung dalam puisi saat pengolahan data.

\section{HASIL DAN PEMBAHASAN}

Hasil dan pembahasan pada penelitian ini dipaparkan berdasarkan hasil analisis terhadap unsur stilistika dari (1) puisi berjudul Husspuss, (2) puisi berjudul $O$, (3) puisi berjudul Mantera, (4) puisi berjudul Sepisaupi, dan (5) puisi berjudul Tapi yang kelimanya ditulis oleh Sutardji Calzoum Bachri.

\section{Puisi Berjudul Husspuss Karya Sutardji Calzoum Bachri}

\section{HUSSPUSS}

husspuss

Diamlah

Kasihani mereka

Mereka sekedar penyair

Husspuss

Maafkan aku

Aku bukan penyair sekedar

Aku depan

Depan yang memburu

Membebaskan kata

memanggilMu

pot pot pot

pot pot pot

kalau pot tak mau pot

biar pot semau pot

mencari pot

pot

hei Kau dengar mantraku

Kau dengar kucing memanggilMu

Izukalizu

Mapakazaba itasatali

tutulita

Papliko arukazuku kodega zuzuzkalibu

Tutukaliba dekodega zamzam lagotokoco

Zuzuzangga zegezegeze zege

Zegeze zukuzangga zegezegeze zukuzang

Ga zegezegeze zukuzangga zegrzegeze zu

Kuzangga zegezegeze aahh...!

Nama nama kalian bebas

Carilah tuhan semaumu 


\section{Amuk (Sutardji Calzoum Bachri)}

Pada puisi Husspuss tersebut, larik 20 sampai 28 terdiri atas kata berupa bunyibunyi bahasa yang tidak mempunyai pengertian. Kata-kata itu asing dalam bahasa Indonesia jika dikaji dalam berbagai segi. Panjang kata terdiri atas empat sampai tujuh suku kata. Rentetan suku katanya berupa urutan konsonan dan vokal secara berurutan dengan pola vkvkvkv. Pengulangan bunyi pot dari larik 12-17 yang kurang jelas maknanya sehingga terdapat asonansi bunyi /o/ yang dominan di baris ke 12-17. Bunyi /o/ berkesan pokok dan kokoh. Struktur fonem yang didominasi /e/, /u/ dan/z / pada baris ke 25-28 memberikan kesan murung, lemah gemulai dan berdesis. Penggunaan bunyibunyi seperti ini tidak lazim dalam bahasa Indonesia.

Seandainya ada sajak yang terdiri dari bunyi-bunyi seperti ini saja tanpa ada kata yang punya pengertian, akan sulit sekali untuk melakukan interpretasi. Puisi itu menarik karena keestetisannya. Segi estetis yang ditimbulkan karena keanehan yang diciptakan. Dalam keadaan tertentu unsur bunyi dapat berfungsi tanpa makna, namun hal itu hanya akan tercipta jika ada konvensi (kesepekatan) pengetahuan pada pihak pembaca jika kata yang tidak bermakna itu bisa dan harus diberi makna disebut sebagai penyimpangan bahasa.

Penyimpangan bahasa sering menjadi ciri dari suatu periode sastra. Dalam puisi Husspuss terdapat tiga bentuk penyimpangan bahasa. Pertama, penyimpangan leksikal, yakni kata-kata yang digunakan dalam puisi menyimpang dari kata-kata yang kita pergunakan sehari-hari. Penyair memilih kata-kata yang sesuai dengan pengucapan jiwanya dan disesuaikan dengan tuntutan estetis.

Kedua, penyimpangan sintaksis. Puisi tidak membentuk kalimat. Namun membentuk larik-larik. Dapat kita lihat jika penyair sering kalap dalam menggunakan huruf kapital pada awal larik dan mengakhirinya dengan titik. Bahkan, tidak ada sama sekali yang mengunakan kaidah tersebut. Ketiga, penyimpangan grafologis. Dalam menulis kata-kata, kalimat, larik dan baris, penyair sengaja melakukan penyimpangan dari kaidah bahasa yang sudah berlaku.

Huruf kapital dan tanda baca tidak digunakan sebagaimana mestinya. Hal ini dilakukan oleh penyair untuk mendapatkan efek estetis. Penyimpangan sistem tulisan seperti itu biasa disebut penyimpangan grafologis. Dalam puisi, Sutardji berani menyimpang dari kebiasaan kode dan norma kebahasaan bahasa Indonesia. Sutardji sendiri mengatakan bahwa puisinya adalah mantra, alat bahasa yang gaib, yang memungkinkan manusia menghubungi atau menguasai dunia yang di luar kemampuannya atau jangkauanya yang normal. Namun, pernyataan tersebut juga tidak berarti bahwa sajak Sutardji sama sekali keluar dari konvensi bahasa. Sebab, dalam puisi Husspus pun penyimpangan hanya mungkin berkat kode yang ada. Pemberontakan hanya akan ada jika ada yang "diberontaki". Interpretasi penyimpangan dan pemberontakan hanya mungkin dalam relasi dan kontras dengan apa yang disimpangi.

Secara garis besar, unsur keidahan yang menonjol dalam pusi Husspuss tersebut adalah unsur diksi yang tidak lazim dan berusaha membebaskan diri dari konvensi tata bahasa yang lazim digunakan. 


\title{
Puisi Berjudul $O$ Karya Sutardji Calzoum Bachri
}

\author{
$\mathbf{O}$ \\ dukaku dukakau dukarisau dukakalian dukangiau \\ resahku resahkau resahrisau resahbalau resahkalian \\ raguku ragukau raguguru ragutahu ragukalian \\ mauku maukau mautahu mausampai maukalian maukenal maugapai \\ siasiaku siasiakau siasia siabalau siarisau siakalian siasia \\ waswasku waswaskau waswaskalian waswaswaswaswaswaswaswaswaswas \\ duhaiku duhaikau duhairindu duhaingilu duhaikalian duhaisangsai \\ oku okau okosong orindu okalian obolong o risau o Kau O...
}

(Sutardji Calzoum Bachri)

Dalam puisi $O$, Sutardji memilih diksi yang tepat, sesuai dengan apa yang dia katakan bahwa kata itu adalah pengertian itu sendiri tidak harus bermakna lain. Dalam puisi $O$ hanya ada makna denotasi. Dalam puisi tersebut, kata-kata yang digunakan penyair adalah kata-kata yang bisa digunakan dalam bahasa sehari-hari. Akan tetapi, ada kata yang berasal dari bahasa daerah antara yaitu bahasa Jawa, terlihat pada diksi "bolong" yang berarti berlubang.

Di sisi lain, hanya sedikit kata yang menimbulkan efek efoni atau teknik memindahkan bunyi, antara lain duhairindu, duhaingilu, duhaisangsai, orindu, obolong, dan orisau. Akibatnya, puisi tersebut tidak terlihat kemerduannya, walaupun banyak terdapat asonansi seperti pada larik-larik berikut.

\author{
Dukaku dukakau dukarisau \\ Resahku resahkau resahrisau resahbalau \\ Raguku ragukau raguguru ragutahu \\ Mauku maukau mautahu mausampai........maugapai \\ Siasiaku siasiakau...... siasiabalau siasiarisau \\ Waswasku waswaskau \\ Duhaiku duhaikau duhairindu duhai ngilu
}

Asonansi yang ada tersebut tetap saja menimbulkan efek kakafoni. Oleh karena kesan bunyi indahnya seperti bunyi dalam mantra, asonansi pada puisi $O$ terkesan biasa dan tidak merdu. Begitu juga pada iramanya, paduan bunyi pada larik puisi $O$ hanya membuat irama yang datar-datar saja sehingga tak ada luapan-luapan emosi yang bisa mempengaruhi irama. Bahasa kiasan yang ditampilkan adalah repetisi, yakni pengulangan kata guna menekankan arti pada kata itu. Seperti tekanan pada kata "duka" yang diulang sampai lima kali terlihat kalau sang penyair sedang mengalami duka entah duka pada dirinya, pada kau atau mungkin kekasihnya, duka pada temannya ataupun duka seekor kucing.

Begitu juga penekanan pada diksi resah, ragu, mau, sia-sia, waswas, duhai, dan $o$ adalah sebuah tekanan yang memberi makna lebih pada duka, keresahan yang akhirnya menimbulkan ragu dan juga keingintahuan walaupun itu hanya sia-sia serta membuat waswas. Pengulangan kata itu merupakan penekanan juga pada artinya.

Dalam puisi $O$ terdapat beberapa pencitraan, antara lain, gerak, pendengaran, 
perasa, dan penglihatan. Gerak terlihat dari kata"maugapai" karena seakan kita bergerak untuk menggapai harapan itu. Pendengaran terlihat dari kata "dukangiau" karena kata ngiau dalam puisi tersebut adalah suara hewan yakni kucing sebagai suatu bahan perbandingan. Indera perasa juga terasa dilibatkan dalam kata "duhaingilu" sehingga pembaca seakan ikut merasa ngilu dengan membaca puisi tersebut. Selain itu juga ada pencitraan penglihatan pada kata "okosong" dan "obolong" karena kosong dan bolong itu hanya bisa diketahui melalui indera penglihatan.

Semuanya merupakan pencintraan yang bertujuan membawa pembaca dengan segenap inderanya sehingga bisa merasakan sakit dan kehampaan yang ada dalam puisi tersebut. Dengan melibatkan indera, suasana puisi bisa dirasakan dengan seluruh imajinasi, termasuk apa yang ada dalam puisi tersebut. Kata-kata yang seakan berupa mantra itu merupakan ekspresi dari doa. Penyair merasa duka, resah, dan ragu yang mendalam. Perasaan itulah yang membuat penyair berkeinginan untuk mencapainya walaupun semuanya harus sia-sia dan menyisakan perasaan waswas dan kehampaan. Kehampaan yang dirasakan itu dilambangkan dengan kata "bolong" dan "kosong" yang seakan-akan seperti huruf O.

Jadi, sebenarnya huruf $\mathrm{O}$ adalah penggambaran dari perasaan hampa dan kosong sang penyair. Selain itu, kata-kata dalam puisi yang disusun seperti mantra seakan-akan menyiratkan bahwa puisi tersebut adalah doa. Jadi, puisi tersebut merupakan hakikat dari Tuhan dan dosa. Artinya, tentang bagaimana manusia merasa berdosa dengan segala keresahan dan kesedihan sehingga semuanya hanya bisa dikembalikan kepada Tuhan.

Sajak tersebut menggambarkan suasana optimis pada penyair. Suasana optimis tersebut berubah menjadi absurd, karena, walaupun sudah merasa tidak mungkin, masih ada usaha untuk menggapai semua itu. Dengan demikian, puisi $O$ menyiratkan keyakinan bahwa semuanya akan bisa tercapai walaupun hal itu tidak mungkin dilakukan. Jika dipahami, sajak tersebut kata-katanya dikusai oleh emosi dan rasio yang tak menentu sehingga menjadi sebuah misteri. Sebab, semuanya seakan hanya sebuah misteri yang seakan-akan sulit dipahami dan terlihat tidak komunikatif.

Dalam puisi $O$, Sutardji memilih kata-kata yang sangat luar biasa. Bahasa yang digunakan mengartikan bahwa pengertian kata-kata tersebut mewakili kata itu tanpa melibatkan kata yang lain. Dengan demikian, dalam puisi $O$ hanya ada makna denotasi. Dalam puisi tersebut, kata-kata yang digunakan Sutardji adalah bahasa yang dipergunakan dalam keseharian sehingga mudah dipahami baik bahasa ibu atau bahasa pada umumnya, tetapi ada juga kata yang berasal dari bahasa Jawa, terlihat pada kata "bolong" yang berarti berlubang atau mengandung makna suatu kekosongan atau tidak berisi apa-apa.

\section{Puisi Berjudul Mantera Karya Sutardji Calzoum Bachri}

\section{Mantera}

lima percik mawar

tujuh sayap merpati

sesayat langit perih

dicabik puncak gunung

sebelas duri sepi

dalam dupa rupa 
tiga menyan luka

mengasapi duka

puah!

kau jadi Kau!

Kasihku

Dilihat dari bentuk sajaknya, sajak Mantera terdiri atas dua bait yang tidak simetris. Bait pertama terdiri atas delapan larik dan yang kedua terdiri atas tiga larik. Keadaan yang tidak sebanding tersebut memberi kesan berat dan adanya tekanan. Sesuai dengan judul, interpretasi yang timbul kemudian adalah adanya masalah, dan untuk mengembalikan pada keadaan semula, pada harmoni, diperlukan mantra. Ditinjau dari rimanya, tidak banyak rima yang terdapat pada larik-larik awal atau akhir seperti yang biasanya terdapat pada sajak tradisional, tetapi persamaan bunyi vokal selarik atau asonansi banyak ditemukan. Memang, mantra pada prinsipnya adalah permainan bunyi.

Sajak yang terdiri dari 28 kata tersebut hanya mengandung dua verba yang salah satunya merupakan bentuk pasif (dicabik), sedangkan yang lain merupakan bentuk nomina dan adjektiva. Hal tersebut memberi kesan statis seperti juga dukun yang sedang mengucapkan mantra di depan kemenyannya. Meskipun demikian, tak adanya tanda baca selain dua tanda seru, serta tiadanya huruf besar, menimbulkan kesan adanya suatu gerakan yang tak berhenti, bagaikan asap yang mengepul tinggi.

Sementara itu, kedua tanda seru menunjukkan fungsi ekspresif yang kuat. Selanjutnya, sebagaimana telah dikatakan di atas, judul sajak tersebut adalah Mantera. Apabila diperhatikan, semua kosakata yang digunakan sangat mendukung fungsi ekspresif. Diksi /lima percik mawar/ adalah air mawar yang biasa digunakan oleh dukun dalam berdoa. Demikian pula diksi /tujuh sayap merpati/. Pada umumnya yang digunakan sebagai korban adalah ayam hitam. Namun, di sini digunakan jenis unggas lain, yaitu merpati. Hal tersebut menunjukkan bahwa Sutardji ingin menunjukkan bahwa tidak selalu hitam itu simbol keburukan. Selanjutnya, diksi /sesayat langit perih/ menunjukkan adanya suatu kesakitan atau kesedihan yang membutuhkan mantra.

Sajak Mantera juga menarik dari aspek pragmatisnya. Apabila bait pertama dikemukakan oleh pencerita untuk menampilkan keadaan sang dukun yang sedang berdoa, bait kedua hanya berisi komunikasi langsung antara dukun dengan penguasa alam semesta. Itulah sebabnya bagian kedua sangat ekspresif. Seruan /Puah/ dilontarkan sang dukun pada akhir doanya, biasanya disertai ludah yang dianggap mempunyai kekuatan gaib dan kekuatan penyembuh. Diksi / $k a u /$ yang ditampilkan dengan huruf " $k$ " kecil, berubah menjadi /Kau/ dengan huruf " $k$ " kapital yang berarti si dukun telah berhasil menyatu dengan penguasa alam semesta yang disebutnya dan dianggapnya sebagai /Kasihku/.

Sementara gaya bahasa yang terdapat dalam puisi tersebut menggunakan gaya bahasa hiperbola membandingkan sesuatu dengan yang lain. Hal ini seperti yang terlihat pada larik /sesayat langit perih/. Diksi /langit/ mengandung makna yang begitu luas atau sesuatu tempat untuk bernaung, namun dalam puisi tersebut menggambarkan kepedihan yang begitu dalam.

Selanjutnya dalam larik /dicabik puncak gunung/, Sutardji ingin mengungkapkan benda yang mati seolah-olah dapat bergerak, dapat melakukan apa yang dilakukan oleh manusia. Hal tersebut bertujuan untuk mendukung suasana pada larik berikutnya yaitu 
suasana sepi dan duka yang sangat medalam. Seperti tampak pada larik //sebelas duri sepi/dalam dupa rupa/tiga menyan luka/mengasapi duka/l. Jika dicermati, puisi-puisi yang diciptakan Sutardji tidak terlalu menonjolkan makna kias. Oleh karena itu, dalam puisinya Sutardji lebih memilih menggunakan kata denotatif dan permainan kata.

\section{Puisi Sepisaupi Karya Sutardji Calzoum Bachri}

\section{Sepisaupi}

sepisau luka sepisau duri

sepikul dosa sepukau sepi

sepisau duka serisau diri

sepisau sepi sepisau nyanyi

sepisaupa sepisaupi

sepisapanya sepikau sepi

sepisaupa sepisaupi

sepikul diri keranjang duri

sepisaupa sepisaupi

sepisaupa sepisaupi

sepisaupa sepisaupi

sampai pisauNya ke dalam nyanyi

(Sutardji C. Bachri 1973)

Berangkat dari penyusunan kata, puisi Sepisaupi sangatlah khas terutama pada permainan bahasa yang digunakan. Hal tersebut dapat dilihat pada penggabungan beberapa kata sekaligus seperti pada larik-larik berikut.

$$
\begin{aligned}
& \text { sepi }+ \text { pisau } \rightarrow \text { sepisau } \\
& \text { sepi }+ \text { pikul } \rightarrow \text { sepikul } \\
& \text { sepi }+ \text { pukau } \rightarrow \text { sepukau } \\
& \text { sepi }+ \text { pisau }+ \text { apa } \rightarrow \text { sepisaupa } \\
& \text { sepi }+ \text { pisau }+ \text { api } \rightarrow \text { sepisaupi }
\end{aligned}
$$

Pertautan-pertautan kata tersebut menimbulkan satu kata baru yang unik sehingga hal itu mengharuskan pembaca untuk keluar dari bingkai pemaknaan konvensional. Diksi /luka/ bersanding dengan diksi /duri/, diksi /dosa/ dengan /sepi/, diksi /duka/ dengan /diri/, diksi /sepi/ dengan /nyanyil, diksi /diri/ dengan /duri//. Pasangan-pasangan kata tersebut membuat pembaca harus merekonstruksi ulang mengenai pemaknaan kata yang telah terekam dalam memori.

Lebih jauh, di sinilah kekuatan Sutardji untuk mengeluarkan kata dari beban makna yang disandang selama ini. Kata-kata tersebut menghasilkan bentukan kata dan makna yang lain. Dari segi unsur bentuk, keindahan puisi tersebut terlihat pada perulangan bunyi yang ditimbulkan dari rima. Rima puisi tersebut digarap sangat mengesankan oleh Sutardji dengan menggunakan pola rima /a a/, yaitu di setiap akhir larik puisi ini diakhiri dengan bunyi /i/ sehingga menimbulkan suasana bunyi yang merdu dan indah. 
Permainan kata yang dilakukan Sutardji banyak kita dapati dalam puisi Sepisaupi. Yang paling menonjol adalah pada diksi /sepisaupil. Seperti yang sudah dijelaskan sebelumnya, kata tersebut merupakan hasil dari penggabungan beberapa kata. Kata tersebut yaitu /sepi/, /pisau/, /api/. Jika kita perhatikan setiap kata tersebut mengandung vokal /i/.

Selain itu, puisi tersebut juga banyak menggunakan bunyi konsonan /s/ dan /p/. Efek /s/ dan /p/ pada "sepisaupi" menimbulkan efek magis dan efek penggunaan fonem tersebut berpengaruh pada pengucapan puisi yang dibaca dengan cepat dan terdengar seperti mantra. Pengulangan bunyi vokal yang sama pada kata atau perkataan yang berurutan dalam baris-baris puisi menimbulkan kesan kehalusan, kelembutan, kemerduan atau keindahan bunyi. Hal ini dapat dilihat pada diksi /Sepisaupa/Sepisaupi/Sepisapanyal/.

Pengulangan bunyi konsonan yang sama dalam baris-baris puisi biasanya pada awal kata atau perkataan yang berurutan. Pengulangan seperti itu menimbulkan kesan keindahan bunyi. Efek magis ditimbulkan Sutardji melalui pengulangan kata serta pengobrak-abrikan kata dalam puisi "Sepisaupi". Kata /sepisaupi/ jika didengarkan seperti mantra. Hal itu disebabkan penggabungan kata-kata /sepi/ dan /pisau/ jika dibaca tanpa putus kita akan dapat menangkap makna dari sepi dan pisau itu. Efek /s/ dan /p/ pada "sepisaupi" menimbulkan efek magis, dan efek penggunaan fonem tersebut berpengaruh pada pengucapan puisi yang dibaca dengan cepat dan terdengar seperti mantra.

Efek magis yang murni pada puisi tersebut juga dapat dilihat dari penggunaan gaya bahasa pengulangan (repetisi). Diksi /Sepisau, sepisaupa, sepisaupi/, begitu banyak diulang-ulang dalam puisi ini. Bila diperhatikan lebih lanjut, efek yang diperoleh dari perulangan kata-kata yang tidak jelas artinya itu seakan-akan menunjukkan sesuatu yang gaib. Dalam puisi, penyair menggunakan gambaran-gambaran angan untuk memberi gambaran yang jelas, menimbulkan suasana yang khusus, membuat gambaran dalam pikiran dan penginderaan lebih hidup, serta untuk menarik perhatian,. Hal tersebut juga dapat dilihat dari bait kedua yang isinya tidak jauh berbeda, yaitu menceritakan tentang sebuah penderitaan larik /sepikul diri keranjang duri/. Larik tersebut mengandung majas hiperbola yang digunakan untuk memperkuat makna penderitaan yang luar biasa.

Unsur dominan yang mampu menunjukkan konsep estetis dalam puisi Sepisaupi adalah bunyi. Secara estetis, puisi tersebut memiliki bentuk puisi yang sedikit berbeda, tidak ada keteraturan yang ada dalam bentuk nyata dapat dikatakan berbentuk bebas. Meskipun pengarang banyak menggunakan kata-kata yang tabu, hal itu tidak mengurangi nilai keindahannya. Sebaliknya, hal tersebut membuat puisi Sepisaupi semakin menarik dan memiliki kesan yang berbeda.

Penggunaan vokal /i/, /u/, /a/ ini dapat menimbulkan suasana gembira, bahagia, riang, kasih, suci, kecil, ramping, ringan, dan tinggi. Penggunaan konsonan /s/ dan /p/ menimbulkan suasana kacau, tidak teratur, dan tidak menyenangkan. Efek magis yang murni pada puisi tersebut juga dapat kita lihat dari pengulangan-pengulangan (repetisi) seperti pada mantra. Diksi /sepisau, sepisaupa, sepisaupi/, begitu banyak diulang-ulang dalam puisi tersebut. Puisi-puisi sejenis ini memang tidak terlalu kuat dalam gaya bahasa, simbol, atau permainan kata. Puisi-puisi yang diciptakan Sutardji lebih mementingkan teori pemecahan (fungsi) kata, permainan bentuk, pemaknaan baru, dan ingin mengembalikan kata pada mantra.

Penyair juga menggunakan kata ganti untuk menyebutkan Tuhan dengan kata Nya yang ditulis tanpa spasi dengan kata /pisau/ di baris terakhir. Kata ganti tersebut juga 
menggunakan huruf kapital pada awal huruf kata ganti tersebut. Penggunaan kata tersebut dimanfaatkan oleh penyair bahwa penanda bahwa Nya yang dimaksud adalah Tuhan.

Repetisi yang digunakan oleh penyair terdapat pada pengulangan afiks se- yang terdapat pada awal kata. Penggunaan repetisi afiks se- ini digunakan oleh penyair untuk memunculkan efek estetik pada puisi. Repetisi juga digunakan oleh penyair pada pengulangan frasa /sepisaupa/sepisaupi/. Pengulangan ini digunakan untuk menekankan frasa /sepisaupa/sepisaupil.

\section{Puisi Berjudul Tapi Karya Sutardji Calzoum Bachri}

\section{TAPI}

aku bawakan bunga padamu
tapi kau bilang masih
aku bawakan resah padamu
tapi kau bilang hanya
aku bawakan darahku padamu
tapi kau bilang cuma
aku bawakan mimpiku padamu
tapi kau bilang meski
aku bawakan dukaku padamu
tapi kau bilang tapi
aku bawakan mayatku padmu
tapi kau bilang hampir
aku bawakan arwahku padamu
tapi kau bilang kalau
tanpa apa aku datang padamu
wah!

Sutardji Calzoum Bachri

Puisi TAPI Karya Sutardji Calzoum Bachri tersebut menggunakan beberapa gambaran kata seperti gambaran manusia, gambaran kesakitan, dan gambaran usaha. Pertama, gambaran manusia terdiri atas diksi /aku, kau, mayat, dan arwah/. Kata /aku/ dan $/ \mathrm{kau} /$ merupakan kata ganti orang yaitu kata ganti orang pertama dan kata ganti orang kedua. Namun, /kau/ dalam puisi ini bukan merupakan gambaran manusia tetapi makna sebagai Tuhan. Mayat adalah bentuk jasad dari manusia yang telah meninggal dunia. Dalam puisi ini, si aku adalah manusia. Oleh karena itu, diksi mayat tentu merujuk pada mayat manusia, sedangkan arwah adalah roh atau berupa benda abstrak yang lebih kita kenal sebagai jiwa dari mahluk yang salah satunya dimiliki oleh manusia. Kata /arwah/ dapat dimasukkan sebagai gambaran manusia karena arwah yang tertera dalam puisi adalah arwah yang dibawa oleh si aku.

Kedua, gambaran kesakitan. Gambaran kesakitan yang terdapat dalam puisi itu adalah resah dan duka. Kata /resah/ adalah sebuah perasaan galau atau gelisah yang dialami manusia. Kata /resah/ bisa digolongkan dalam gambaran kesakitan karena resah itu membuat orang yang mengalaminya susah melakukan sesuatu karena dibebani oleh perasaan ini. Diksi /duka/ merupakan antonim dari kata /suka/. Duka adalah perasaan kepedihan dan kesengsaraan yang dialami manusia seperti saat kehilangan dan kata 
tersebut bisa digolongkan dalam gambaran kesakitan karena duka akan membuat perasaan orang yang mengalaminya menjadi sakit dan sedih.

Ketiga, gambaran usaha. Diksi yang dapat digolongkan pada gambaran usaha adalah kata /bawakan, bilang, dan datang/. Diksi /bawakan/ merupakan kata kerja yaitu bawa yang berasal dari kata membawa yang mendapat imbuhan -kan. Kata /bilang/ adalah kata yang biasanya dilakukan oleh tindak tutur manusia seperti kata berucap atau berbicara. Selanjutnya, kata /datang/ yang merupakan usaha untuk menuju suatu tempat.

Sementara gaya itu, bahasa yang digunakan pada puisi tersebut adalah hiperbola yaitu gaya bahasa yang melebih-lebihkan. Seperti pada baris berikut /aku bawakan mayatku padamu/. Secara logika, mungkin mayat diri sendiri bisa dibawa ke hadapan Tuhan. Penggambaran tersebut tentu sangat berlebihan.

Puisi TAPI karya Sutardji Calzoum Bachri tersebut memiliki beberapa citraan, di antaranya citraan gerak dalam larik laku bawakan bunga padamu/. Citraan kesedihan yang tergambar pada larik laku bawakan mayatku padamu/. Tema dari puisi TAPI karya Sutardji Calzoum Bachri adalah hubungan antara seorang hamba dengan Tuhan-Nya. Hal tersebut dapat dilihat pada setiap baris yang terletak pada puisi tersebut seperti pada baris pertama yaitu /aku bawakan bunga padamu/. Kata /bungal merupakan makna konotasi karena seorang hamba tidak akan membawa hal-hal demikian saat menghadap dengan penciptanya, sama halnya dengan kata / resah, darah, mimpi, arwah, mayat, dan dukal yang terletak pada baris selanjutnya sedangkan kata /bilang/ pada puisi merupakan makna konotasi dari firman karena Tuhan.

Puisi TAPI karangan Sutardji Calzoum Bachri menggambarkan sebuah pertentangan antara $a k u$ dan kau sehingga apa pun yang dibawa oleh $a k u$ selalu tak bermakna di mata kau. Adanya pemisahan antara baris aku dan kau seolah menggambarkan percakapan antara dua orang yang derajat atau statusnya tidak akan pernah sejajar, seperti seseorang yang sedang menjalin asmara atau juga seperti hubungan antara hamba dengan Tuhannya.

Dalam menciptakan puisi tersebut, Sutardji ingin mengungkapkan bahwa derajat manusia tidak akan tinggi di pandangan Tuhan apabila manusia tersebut menyombongkan sesuatu apa yang mereka punya. Inti makna dari puisi tersebut adalah bahwa seorang manusia yang dilambangkan dengan diksi $a k u$ janganlah merasa tinggi dengan orang lain karena di atas kita masih ada langit, yaitu Tuhan.

\section{KESIMPULAN}

Puisi dipandang sebagai karya sastra yang memiliki unsur-unsur estetis seperti yang terdapat pada sajak berjudul Husspuss, O, Mantera, Sepisaupi, dan Tapi yang mewakili sebagian dari puisi kontemporer karya Sutardji Calzoum Bachri. Dalam puisi tersebut diperoleh unsur-unsur yang mampu menciptakan dan menimbulkan nilai estetis atau keindahan antara lain diksi, imaji, bahasa kiasan, dan sarana retorika yang tergabung dalam karakteristik bahasa. Selanjutnya, terdapat unsur rima, perulangan bunyi yang tergabung dalam karakteristik bunyi dan makna puisi yang termasuk dalam isi sebuah puisi. Namun, yang paling menonjol dalam pembangunan konsep estetis pada puisi kontemporer atau unsur yang mendapat tekanan yang tepat ialah diksi atau pilihan kata.

Diksi dalam puisi kontemporer Sutardji Calzoum Bachri mendorong unsur-unsur lainnya untuk membentuk keselarasan dan akhirnya dapat membentuk kesatuan makna 
yang utuh, yang dari segi makna juga mengandung nilai estetis. Sementara, gaya bahasa yang terdapat dalam puisi-puisi kontemporer tersebut kurang mendapat perhatian dari sang penyair. Penyair hanya menggunakan beberapa gaya bahasa seperti gaya bahasa hiperbola dan repetisi.

\section{UCAPAN TERIMA KASIH}

Artikel ini merupakan hasil penelitian yang diselenggarakan STKIP-PGRI Lubuklinggau dengan judul Diksi dan Gaya Bahasa Puisi-Puisi Kontemporer Karya Sutardji Calzoum Bachri (Sebuah Kajian Stilistik). Ucapan terima kasih kepada Lembaga STKIP-PGRI Lubuklinggau yang sudah memfasilitasi pelaksanaan penelitian sebagai wujud pelaksanaan Tri Darma Perguruan Tinggi. Selanjutnya, ucapan terima kasih disampaikan kepada mitra bestari dan editor Aksis yang telah mendukung penerbitan artikel penelitian ini.

\section{REFERENSI}

Endraswara, S. (2011). Metodelogi Penelitian Sastra. Yogyakarta: CAPS.

Lastari, A. (2017). Pandangan dunia pengarang dalam kumpulan puisi Blues untuk Bonnie karya Rendra (Kajian Strukturalisme Genetik). Jurnal AKSIS: Jurnal Pendidikan Bahasa dan Sastra Indonesia, 1(1), 63-79. doi: https://doi.org/10.21009/AKSIS.0101

Munir, S. (2013). Diksi dan majas dalam kumpulan puisi Nyanyian dalam Kelam karya Sutikno W.S.: Kajian stilistika. Jurnal Sastra Indonesia, 2(1), 1-10. doi: https://doi.org/10.15294/jsi.v2i1.2437

Nurgiyantoro, B. (2010). Teori Pengkajian Fiksi. Yogyakarta: Gadjah Mada University Press.

Nurhayati. (2008). Teori dan Aplikasi Stilistik. Palembang: Penerbit Unsri.

Pradopo, R.D. (2002). Kritik Sastra Modern. Yogyakarta: Gama Media.

Pradopo, R.D. (2010). Pengkajian Puisi. Yogyakarta: Gadjah Mada University Press.

Purwahida, R. (2017). Interaksi sosial pada kumpulan cerpen Potongan Cerita di Kartu Pos karangan Agus Noor dan implikasinya terhadap pembelajaran sastra di SMA. Jurnal AKSIS: Jurnal Pendidikan Bahasa dan Sastra, 1(1), 118-134. doi: https://doi.org/10.21009/10.21009/AKSIS.010107

Purwahida, R. (2018). Problematika Pengembangan Modul Pembelajaran Baca Tulis Anak Usia Sekolah Dasar. Aksis: Jurnal Pendidikan Bahasa dan Sastra Indonesia 2(1). 118-134. doi: doi.org/10.21009/AKSIS.020108

Ratna, N.K. (2009). Stilistika, Kajian Puitika Bahasa, Sastra, dan Budaya. Yogyakarta: 
Pustaka Pelajar.

Suhita, S. \& Purwahida, R. (2018). Apresiasi Sastra Indonesia. Bandung: Remaja Rosdakarya.

Supriyanto, T. (2011). Kajian Stilistika dalam Prosa. Yogyakarta: Elmetera Publishing. 